\title{
Expanding the Practice of Newsmaking Criminology to Enlist Criminologists, Criminal Justicians, and Social Workers in Shaping Discussions of School Violence: A Review of School Shootings from 1992-2013
}

\author{
Kelley Reinsmith-Jones ${ }^{1}$, James F. Anderson ${ }^{2}$, Adam H. Langsam ${ }^{3}$ \\ ${ }^{1}$ College of Health and Human Performance, Assistant Professor of Social Work, East Carolina University, Greenville, \\ NC, USA. \\ ${ }^{2}$ College of Arts and Sciences, Professor of Criminal Justice, East Carolina University, Greenville, NC, USA. \\ ${ }^{3}$ College of Liberal Arts, Professor of Sociology, Northeastern State University, Tahlequah, OK, USA. \\ Correspondence: James F. Anderson, Professor, Department of Criminal Justice, East Carolina University, Greenville, \\ NC, USA.
}

Received: July 1, 2015

Accepted: July 15, 2015

Available online: July 27, 2015

doi:10.11114/ijsss.v3i5.974

URL: http://dx.doi.org/10.11114/ijsss.v3i5.974

\begin{abstract}
Newsmaking criminology argues that criminologists should interpret, influence, and even shape the direction of newsworthy information about crime and justice to the extent that they aggressively make their presence known by engaging the media. This article calls for an expansion in the practice of newsmaking criminology to also include criminal justicians, as well as social workers when it comes to the issue of school violence. Recently, a number of shootings have occurred on school campuses in rural, urban, and suburban America. When these shootings are reported, they quickly become politicized and generate widespread attention from parents, law enforcement, politicians, community activists, and policy-makers. However, what appears to be missing from the discussion is input from criminologists, criminal justicians, and social workers who could bring a wealth of knowledge and understanding to these atrocities. This study used a random sample of 129 items from over a twenty-one year period in a content analysis to categorize the spokespersons used by the mass media to discuss school violence and school shootings.
\end{abstract}

Keywords: Newsmaking criminology, school shootings, school violence, criminal justicians, criminologists, newsworthy, social workers.

\section{Introduction}

Recently, a number of shootings have occurred on school campuses that have either claimed the lives of or dramatically altered the lives of the nation's children (Wike \& Fraser, 2009). This is particularly disturbing since schools are places of learning, growing, and educational nurturing that are also supposed to be safe havens (Wood, 2005; Schreck \& Miller, 2003; Ripski \& Gregory, 2009). While tragic, these shootings have been instructive in revealing that schools are not the safe places they were decades ago and that random violence can strike anyone and anywhere irrespective of social class position or demographics such as race, ethnicity, or age (Hawkins, McIntosh, Cohen-Silver, \& Holman, 2004; Wike \& Fraser, 2009). For example, in the past five years, shootings have occurred at schools located in urban, rural, and suburban areas. Despite this, an emerging problem that has become obvious is a lack of commentary and analysis from criminologists, criminal justicians, and social workers in discussions that explain school violence, what must be done to treat surviving students, what efforts should be taken to help communities heal, and how to prevent these atrocities from reoccurring. It appears from our point of view that these trained experts have either been construed as unhelpful, or they have not been consulted about juvenile, as well as other crime that plague the nation's schools.

What one finds and reads in local news reports of school shooting tragedies is non-experts such as politicians, leading the dialog on these matters of violence. Consequently, they shape the debate and create images of these crimes, along with their victims, as well as perpetrators. This is troublesome since most of them simply lack the training, expertise, and research experience to offer viable solutions to these problems. For example, when people are ill, most seek the 
help and assistance of a physician. When they need insurance, they seek an agent who is properly trained in providing such services. However, this does not seem to be the case where crime is concerned. When people fall victim to crime, or when they attempt to make sense of crime, they rarely contact criminologists, criminal justicians, or social workers who are professionally trained to address this issue. Unfortunately, the general public looks to reporters, politicians, and police for answers about crime and its causes. Police agencies and officers are ill-equipped to provide such answers since they typically respond to atrocities after they have occurred. However, they may be aware of how to prevent crimes from reoccurring.

With respect to recent school shootings, such as those that occurred in Newtown, Connecticut and North Houston, Texas, one did not see the presence of criminologists, criminal justicians, or social workers who could provide expert analysis on these tragedies. Why are they absent from these discussions? This begs the question, what are criminologists, criminal justicians, and social workers, and can they assist in helping us to better understand and heal from school shootings? Why are they not among those who provide their expertise on violence in general, but on the plight of school safety in America, in particular? This article seeks to address these issues. Therefore, this work defines the role of criminologists, criminal justicians, and social workers. It provides the methodology that examines data sources used by media outlets (to present school violence) in the past twenty-one years. Moreover, this section presents a content analysis that measures who has had ownership of addressing school violence and shooting discussions. It also argues for the need to enlist the help of newsmaking criminologists and expand its practice to include social workers to speak authoritatively on matters related to school violence and community healing. In the final analysis, we argue that the inclusion of criminologists, criminal justicians, and social workers, can add to the public's understanding of school violence and lead to more effective crime prevention policies.

\section{Defining Newsmaking Criminology and Examining the Roles of Criminologists, Criminal Justicians, and Social Workers}

Crime news receives an enormous amount of attention from the media (Surette, 1998; Barak, 1994; Maguire, Sandage, \& Weatherby, 1999). In fact, Surette (1992) argues that there is no other media content given more coverage than matters related to crime and justice. Anyone who watches the local news is aware that "if it bleeds, it leads as a crime story." Jewkes (2004) argues that violence increases the likelihood that a crime story is reported. This statement suggests that local evening and nightly news programs typically lead with reports about crime. However, a major concern of the news media that may be unknown to television viewers is its' struggle to report and present stories that are newsworthy. It prefers factual stories to time fillers that are not typically prepackaged or routine. The media likes new releases because they present topics that are likely to be of interest to viewers and readers (Fedler, Bender, Davenport, \& Kostyu, 1997). In fact, Fedler and colleagues argue that journalists prefer stories that satisfy their definition of news. This includes topics that are new, local, interesting, and relevant. More specifically, they argue that the news media seeks stories that impact or even affect large numbers in the viewing audience. However, Kappeler \& Potter (2005), disagree arguing that crime reporting may be restricted to acts that are gruesome and bizarre that investigative journalists use to uncover certain crime and to ensure a wider viewership and sponsorship. They argue that the competitive nature of the modern media may fuel the engine behind the need to present and create crime problems when they may not exist. Nevertheless, when the media creates myths about crime, they are sustained by other myths related to crime and justice. The continuation of such presentation tends to eventually blind the general public to the realities of crime and justice matters. Consequently, the images that are constructed by the media are impossible to differentiate from the source (Ferrell \& Sanders, 1995; Mills, 1951). If the latter position is true, this could bode well for an emerging group of scholars who engage in the practice of newsmaking criminology.

\subsection{Newsmaking Criminology}

Newsmaking criminology was first coined in 1988 by Gregg Barak and has since been advocated by other criminologists and sociologists, such as Stuart Henry, Cecil Greek, James Fox, and John Levin (See Barak, 1988; 2001; Henry, 1994, 1999; Greek, 1994; Fox \& Levin, 1993). At that time, Barak challenged criminologists to use their training and expertise to initiate discourse with the media instead of solely focusing their efforts in traditional venues, such as classrooms, lecture halls, and academic conferences. More specifically, Barak felt that criminologists could use their knowledge of crime and justice to present realistic images of crime and the justice system that would unmask the sensational treatment that is routinely given to such issues (Greek, 1994). Barak argued that the mass media could be used to reach larger audiences of people. Barak presented an innovative way of enlisting criminologists into discussions of crime to better inform society by becoming activist agents of the media. In essence, he encouraged criminologists to spark the public consciousness regarding the reality of crime and justice. But, can this approach be effective? Put differently, can criminologists take their knowledge and research findings to a wider audience that goes beyond the classroom, or others who attend scientific conferences, or those who read scientific reports? Some scholars argue that it can be achieved, but it requires understanding of how the media operates, how to communicate successfully, and being 
prepared (see Greek, 1994). Similarly, Henry (1994) was optimistic about the feasibility of newsmaking criminology and argued that it is necessary for criminologists to become active participants in influencing the media on matters related to crime and justice. He suggested that criminologists should intercede in the constitutive process (Henry, 1994, 287). Henry goes on to argue that newsmaking criminologists must actively confront and challenge silences, identify omissions, and help create news stories about crime. Put differently, he suggests that criminologists have been silent for too long about factual aspects of crime and justice and have stood in silence when they should have interceded with presenting the "real" reality about crime and justice.

Henry recommends that criminologists offer a replacement discourse as a way of breaking their silence. The new discourse on matters related to crime and justice will interrupt or dismantle what people thought they previously knew and understood about crime and justice reality. Henry and other scholars warn that the new discourse should not be viewed as oppositional discourse, but rather, as a supportive discourse that deconstructs prevailing structures of meanings and replace them with new conceptions, words, and phrases that offer alternative meaning (Henry, 1994; also see Selva \& Bohm, 1984). When this occurs, criminologists will be able to advocate issues of crime and justice as spokespersons, make criminological news, engage in the construction of images of crime and crime control, and eventually impact social change in general, and social justice, in particular (see Barak, 1988; also see Barak \& Bohm, 1989). To facilitate newsmaking criminology, Henry (1994) identifies several styles of newsmaking criminology that have been used. They include: (1) disputing data, (2) challenging journalism, (3) self-reporting, and (4) confronting media. First, disputing data allows the criminologists to reveal expertise by debunking inaccurate facts and false images that shape viewers' and listeners' social reality. Second, the criminologist literally functions as a journalist by presenting newsworthy reports and stories. Third, allows the criminologist to discuss himself or herself. Last, the researcher is an education provocateur. Barak (1998) and Henry (1994) caution that each role comes with advantages and disadvantages that are typically contingent upon the media and the audience to which the criminologist finds himself or herself speaking. For example, these could include print, television, radio, or live versus taped programming (Barak, 1998).

Newsmaking criminology holds that criminologists should use mass communication similar to journalists to gain command of crime and justice subject matter. Thus, allowing them to construct more accurate images of crime, justice, and punishment. This approach should be used to address distortions and to present a more accurate reality. Moreover, Barak (2007) argues that newsmaking criminology strives to demystify existing cultural images of crime and punishments to include all behaviors, (and not just some) that are detrimental to society. In doing so, it should have a pronounced effect on shaping the public debate, influencing attitudes, ideas, and thoughts about crime and justice that will affect crime control policies that are inclusive of all offending behaviors detrimental to society. This will empower criminologists to become stake holders in the discourse, dialog, or narrative on matters related to crime and justice since they will have developed language and technical skills of communication for the public to consume. In essence, newsmaking criminologists are advised to use all mechanisms of the mass media (i.e., radio, television, blogging, print and others) to reach large audiences of listeners and viewers to inform them on matters of crime, law, and justice. They are instructed to act as journalists who shape and direct the public debate on justice related matters.

\subsection{Criminologists}

Criminologists are professionally-trained in the study of crime (Wolfgang \& Ferracuti, 1967, Siegel, 2009). They have formal training and terminal degrees in sociology, criminology, medicine, political science, economics, psychology, or even criminal justice since criminology is an interdisciplinary science (Wright \& Miller, 2005; Barkan, 2006). However, it is safe to say that criminologists devote their careers to the study of crime (Anderson, Mangels, \& Dyson, 2003). They are concerned with the origins of crime, the motivation of criminal behavior, and its trends and patterns that occur over time (Siegel, 2009). Moreover, some criminologists assist lawmakers with decisions to either create new laws or decriminalize existing laws. These same criminologists provide expert opinions on the consequences of either course of action.

Because criminologists have different academic backgrounds and training, they are not all the same, nor do they study the same subject matter. For example, there is great diversity in criminology and what a criminologist may undertake as an area of focus. Siegel (2009) provides that since criminologists are from diverse fields of study, criminology has become an interdisciplinary science that has developed into several subareas that offer specialization that includes: criminal statistics and research methodology, sociology of law, theory construction and testing, criminal behavior systems and crime typologies, penology, and victomology. First, criminologists who use criminal statistics and research methods are concerned with measuring crime. They determine whether there are increases or decreases in the crime rate, and whether crime prevention programs are having a deterrent effect. Second, criminologists who focus on the sociology of law examine the role that social forces play in shaping the law and how the law shapes society. They study how the media and a changing culture influence deviant and criminal behavior. Third, criminologists who are concerned with theory construction and testing make valid predictions about crime and understanding what motivates people to 
break the law. Many of them test hypotheses using empirical research. In the end, they find a variety of reasons why offenders violate the law. Fourth, criminologists who study criminal behavior systems are concerned with crime typologies such as serial killers, intimate-personal violence, organized crime, white collar/corporate crime, sex crimes, and even sexual trafficking in children and adults. Fifth, criminologists who focus on penology are concerned with punishment and controlling offenders. They create crime control strategies that can either treat or punish offenders. Their research is focused on evaluating justice initiatives to determine their efficiency, effectiveness and impact. Last, criminologists who study crime victims are referred to as victimologists. They are concerned with the costs of victimization, levels of crime/victimization, and how much actually occur. In the end, they theorize about future victimization, and study the relationship between offenders and victims. Because of the diversity of academic backgrounds and training, criminologists are imminently qualified to engage in newsmaking criminology.

\subsection{Criminal Justicians}

Criminal justicians are also professionally-trained. They are usually academics (who use the scientific method to support their findings and assertions about offenders and justice processes) or practitioners. This could include employment at the local, state, or federal level (Anderson et al., 2003). These agencies provide criminal justice experts with a wealth of information about the demographics of offenders, the nature and extent of crime, and the geographical distributions of crime, respectively. More specifically, criminal justicians examine how offenders are processed in the justice (juvenile and adult) systems and how those experiences impact offenders' behavior. Many who are now academics were once employed in one of the justice agencies typically as a police officer, parole or probation officer, or as a correctional guard. Their experience as a practitioner affords them the opportunity to "bridge the gap" between theory and practice, and makes them an invaluable resource regarding how the justice systems work.

Lovrich and colleagues (2005) argue that because of advances in technology in the use of fingerprint identification systems, DNA evidence, and the public's fascination with the use of technology to bring offenders to justice, many criminal justice experts have started to engage in forensic science seeking trace evidence that links suspects to crime (Bureau of Justice Statistics, 2000; Swanson, Chamelin, Territo \& Taylor, 2009). Moreover, there has been an increase in the number of crime laboratories. In fact, some estimate that there are 350 federal, state, and local crime laboratories (Swanson et al., 2009). There has also been increased use in cybercrime investigations or electronic crime investigation units where officers pursue online sexual predators, child pornography, and other offenders who engage in other computer-related crimes, such as hacking, identify theft, Internet fraud (e.g., online sale of prostitutes and mail order brides), and cyberstalking to only name a few (Libermann, 2001; Moore, 2005; Schram \& Tibbetts, 2014; Levy \& Stone, 2000).

Others have been involved in homeland security efforts to thwart domestic and global terrorism. In essence, while criminologists are concerned with the motivation behind why people violate the laws that govern society, criminal justicians are focused on processing offenders after they have violated those laws. This may include ensuring that suspects' and the criminally-accused constitutional rights are protected at each stage in the justice process. For example, criminal justice experts must be knowledgeable about issues, such as racial profiling, stop-and-frisk, arrest, informing suspects of Miranda warnings, and interrogations. Therefore, criminal justicians are more versed than criminologists in constitutionally-protected areas, such as rights extended by the First, Fourth, Fifth, Sixth, Eighth, and Fourteenth Amendments. Stated another way, criminal justicians are concerned with processing offenders after they have broken the law. At every stage of the justice process, practitioners must discharge their duties in a constitutionally-correct manner or risk being civilly or criminally responsible for their actions or having the offender go free on a technicality if they fail to ensure equal protection and due process. Put differently, criminologists are concerned with the theoretical, while criminal justice experts are concerned with the applied practitioner-oriented field of study (see Wright \& Miller, 2005). Despite these apparent differences, both criminologists and criminal justicians share a partnership. In fact, some experts believe that the two are inextricably linked to each other and what one does has a pronounced effect on the other (Wright \& Miller, 2005). Since criminal justicians are versed in all matters of the justice process, they are also viewed as imminently qualified to engage in newsmaking criminology.

\subsection{Social Workers}

Social workers are professionally trained in the scientific method as well as in using relational approaches to improve quality of life through various interventions. Because of the problems in society that range from poverty, homelessness, child abuse, drug addiction, violence and family dysfunction to others, social workers are in great demand. In fact, the growth of social work employment is better than most occupations. Recent data from the Bureau of Labor Statistics (2014a) reports a 19\% employment increase from 2012 to 2022, especially in the areas of health care, social services, child, family, and school social work. Moreover, employment of social workers in the mental health and substance abuse jobs has a projected growth of $23 \%$ for the same timeframe. While there is not a projected growth in the number 
of correctional social workers, or correctional treatment specialists, these jobs are quoted as being "plentiful" in the future (Bureau of Labor Statistics, 2014b). The forecasted employment growth in these areas of social work is important because it is in these areas that social workers have the greatest interaction with and impact on violence, its victims, and its perpetrators.

Many social workers are employed by health and social service agencies such as the department of child protective services; family violence prevention programs; early childhood education programs (e.g., Head Start); youth clubs; teen substance abuse programs; adoption; and foster care to only name a few. The primary goal of these efforts is child welfare, which is "services that deal with all aspects of children's well-being, including protecting and promoting their health and social psychological development, strengthening families and addressing adverse social conditions that interfere with . . . health development" (DuBois \& Miley, 2014, p. 365). Consequently, these social workers become deeply involved in the lives of children and families in ways that may require performing assessments, making home-visits, liaising with school or legal officials, and examining family dynamics that may cause trauma and stress. Most interventions are family-based, but some may be child-specific. Working in these capacities, give social workers a hands-on opportunity to address individual and family patterns of coping, perhaps even generational, that are self-harming or harmful to others, including the use of violence.

Forensic social work is a strategy for effecting change in a culture of violence. Although applied in both adult and juvenile correctional systems, it primarily focuses on interacting with youth involved in criminal activity. It is hoped that intervening with minor crime would pre-empt an escalation of violent behavior such as school shootings. These social workers are employed by police departments, juvenile court programs, juvenile probation, and juvenile correctional facilities. They work with both the youth and legal guardians, as well as in collaboration with school authorities (DuBois \& Miley, 2014). In this capacity, these social workers advocate rehabilitative interventions that address troubled and violent behavior. To better address such behaviors, they seek to understand its root causes. These social workers provide consultation, education, and training to correctional systems, law-makers, law enforcement, attorneys, law students, paralegals, and community members and organizations (National Organization of Forensic Social Work, 2014). By assisting in community mobilization efforts, these social workers play a key role in creating safe neighborhoods and reducing violence (Zastrow \& Kirst-Ashman, 2013).

School social workers are an integral part of the child welfare system. In most areas, there may be one social worker assigned to several schools. They provide services to children and their families using several interventions which might include one-on-one counseling, group work, creating mentoring relationships, making referrals, and being a child's advocate as part of a multidisciplinary team that might involve legal guardians, other school personnel, and community representatives such as juvenile probation, physicians or nurses, mental health professionals, and health and social service workers (Haight \& Taylor, 2013). Experts report that interventions focus on educational, psycho-social, and medical concerns of child and adolescent development such as educational achievement, self-esteem, management of emotions, bullying, depression, suicide ideation, homelessness, physical and sexual abuse, teen pregnancy, and teen gang involvement (DuBois \& Miley, 2014). Since social workers are aware of the trauma experienced by children and family members in the aftermath of school shootings that often end in tragedy, they are trained to intervene and assist them in getting the help and resources they need to recover from these traumatic events. Therefore, they are qualified to speak authoritatively on what the community is experiencing and what it needs to heal in the aftermath of school violence that ends in tragedy.

\section{Methods}

This study began in 2012 and ended in 2014. The time frame of this research extended over a one year period. During this time, secondary data sources were collected that chronicled school shootings that occurred at elementary schools, junior-high schools, high schools, and college campuses throughout the United States. The items that were selected for analysis were published over a period of twenty-one years starting in 1992 and ending in 2013. Stated differently, we selected items that were published and presented by the mass media from 1992 to 2013. In our investigation, we used a content analysis to examine articles, newspapers, and television reports. A content analysis is a nonreactive research technique that examines information in documents. More specifically, Kraska \& Neuman (2012) argue that content analysis allows researchers to document specific features or communication in materials that might otherwise go unnoticed. The technique may require that a researcher count the number of times a word, theme, or commonality appear in any form of communication. Hagan (2014) refers to the technique as the systematic classification of the study of mass media, such as journals, governmental documents, newspapers, books, magazines and others. Similarly, Champion (1993) and Bachman \& Schutt (2008) provide that content analysis is the systematic qualitative and quantitative description of some form of communication used for the purpose of discovering patterns and meanings. Bryman (2012) reported that there are two types of content analysis: manifest and latent. Manifest content analysis is used to uncover items that are readily recognizable or apparent for inclusion in an analysis. However, latent content 
requires an interpretation of meaning that is not immediately apparent (Bryman, 2012; Hagan, 2014). This research study used manifest content analysis.

In our research, we examined school shooting data published and presented from 1992 to 2013. We coded and categorized those interviewed and used as spokespersons on the issue of school violence and shootings as either: Police Officer (PO); Politician (P); Reporter (R); Community Activist (CA); Legal Expert (LE), Newsmaking Criminologist (NC), Medical Doctor (MD), School Administrator (SADM), and Teacher (T). More specifically, we defined police officer or law enforcement officer as an investigator responding to investigate a shooting. Politician was defined as a local, state, or federally elected official. Reporter was defined as a news affiliate with a local or national network. A community activist was defined as anyone who expresses an interest in issues that affect his or her community. A legal expert was defined as a lawyer who provides a legal opinion or commentary. A newsmaking criminologist was defined as either: a criminologist, criminal justician, or social worker who offers an expert opinion by using the practice of engaging the media. A medical doctor was someone either at the crime scene or hospital who treated a victim and verbally responded to the issue of violence in school. A school administrator was a principal, a representative from the board of education, or college or university administrator who offered commentary about a shooting at their respective institution.

We further designated the number of sources used in the reports as either: a singular, several, or multiple which addressed whether one, two, or more of the categorizations of spokespersons were used in reports on school shootings. Some experts suggest that when multiple sources are used in reporting, it increases the likelihood those reports will reach a wider audience of people and offer more prospective about what transpired (Hagan, 2014; Fedler, Bender, Davenport, \& Kostyu, 1997). In this investigation, we present two hypotheses. First, newsmaking criminology (as a practice) is not being used (through mainstream news media) to inform the general public about school violence and shootings. Second, reports of school violence and shootings do not use multiple sources that offer an opinion as to why these events transpired.

\subsection{Sample}

From a population of 385 reports, we selected a random probability sample of 129 items $(n=129)$ for the time frame of 1992 to 2013 to engage in a content analysis to categorize the spokesperson used by the mass media to address and discuss school violence and shootings. More specifically, we used a systematic sample by setting an interval of three and then randomly selecting every third report from the total population. The sampling interval was determined by the size of the population. Researchers argue the use of randomly selected samples allow every element in a population an equal probability of being selected. While some researchers argue the systematic sample is not a probability sample, others believe the random starting point of the interval selection allows every element an equal probability of being selected (Lanier \& Briggs, 2014; Babbie, 1995; Champion, 1993; Hagan, 2014). Therefore, it satisfies the requirement of probability theory as long as the sampling frame is noncyclical. Random samples are an excellent way to approximate the population of content used in publications and presentations for the time frame. This allows for valid inferences to be drawn from our findings. Therefore, when random samples are selected using this method, they approximate the target population parameter and allow researchers to generalize or make inferences about a given population (Bachman \& Schutt, 2008; Maxfield \& Babbie, 2011; Hagan, 2014; Kraska \& Neuman, 2012). Because research experts argue that investigators typically make mistakes in coding data, data entry, and analyzing data, we used several coders of the same data to ensure validity. This technique allowed for mistakes to be quickly discovered, discussed, and corrected (Hagan, 2014; Lanier \& Briggs, 2014).

Table 1. Systematic Sample of 67 Items from 1992 To 2001

Table 1(1992-2001)

\begin{tabular}{|c|c|c|c|c|c|c|c|}
\hline YearSource & & & & & Singular & Several & Multiple Total Number \\
\hline & $\mathrm{PO}$, & $, \mathrm{R}, \mathrm{CA}$, & $\mathrm{LE}, \mathrm{NC}, \mathrm{MD}, \mathrm{T}$ & SADM & & & \\
\hline 1. 1992 & $\mathrm{PO}$ & $\mathrm{R}$ & LE & SADM & & & $\mathrm{X}$ \\
\hline 2. 1992 & & $\mathrm{R}$ & & SADM & & $\mathrm{X}$ & \\
\hline 3. 1992 & $\mathrm{PO}$ & $\mathrm{R}$ & & & & $\mathrm{X}$ & \\
\hline 4. 1992 & $\mathrm{PO}$ & $\mathrm{R}$ & & & & $\mathrm{X}$ & \\
\hline 5. 1993 & $\mathrm{PO}$ & $\mathrm{R}$ & & & & $\mathrm{X}$ & \\
\hline 6. 1993 & PO & $\mathrm{R}$ & & & & $\mathrm{X}$ & \\
\hline 7. 1993 & & $\mathrm{R}$ & & & & $\mathrm{X}$ & \\
\hline 8. 1993 & & $\mathrm{R}$ & & & $\mathrm{X}$ & & \\
\hline 9. 1993 & $\mathrm{PO}$ & $\mathrm{R}$ & & & & $\mathrm{X}$ & \\
\hline 10. 1993 & & $\mathrm{R}$ & & & $\mathrm{X}$ & & \\
\hline 11. 1993 & & $\mathrm{R}$ & & & $\mathrm{X}$ & & \\
\hline 12. 1993 & $\mathrm{PO}$ & $\mathrm{R}$ & & & & $\mathrm{X}$ & \\
\hline 13. 1993 & PO & $\mathrm{R}$ & & SADM & & & $\mathrm{X}$ \\
\hline
\end{tabular}




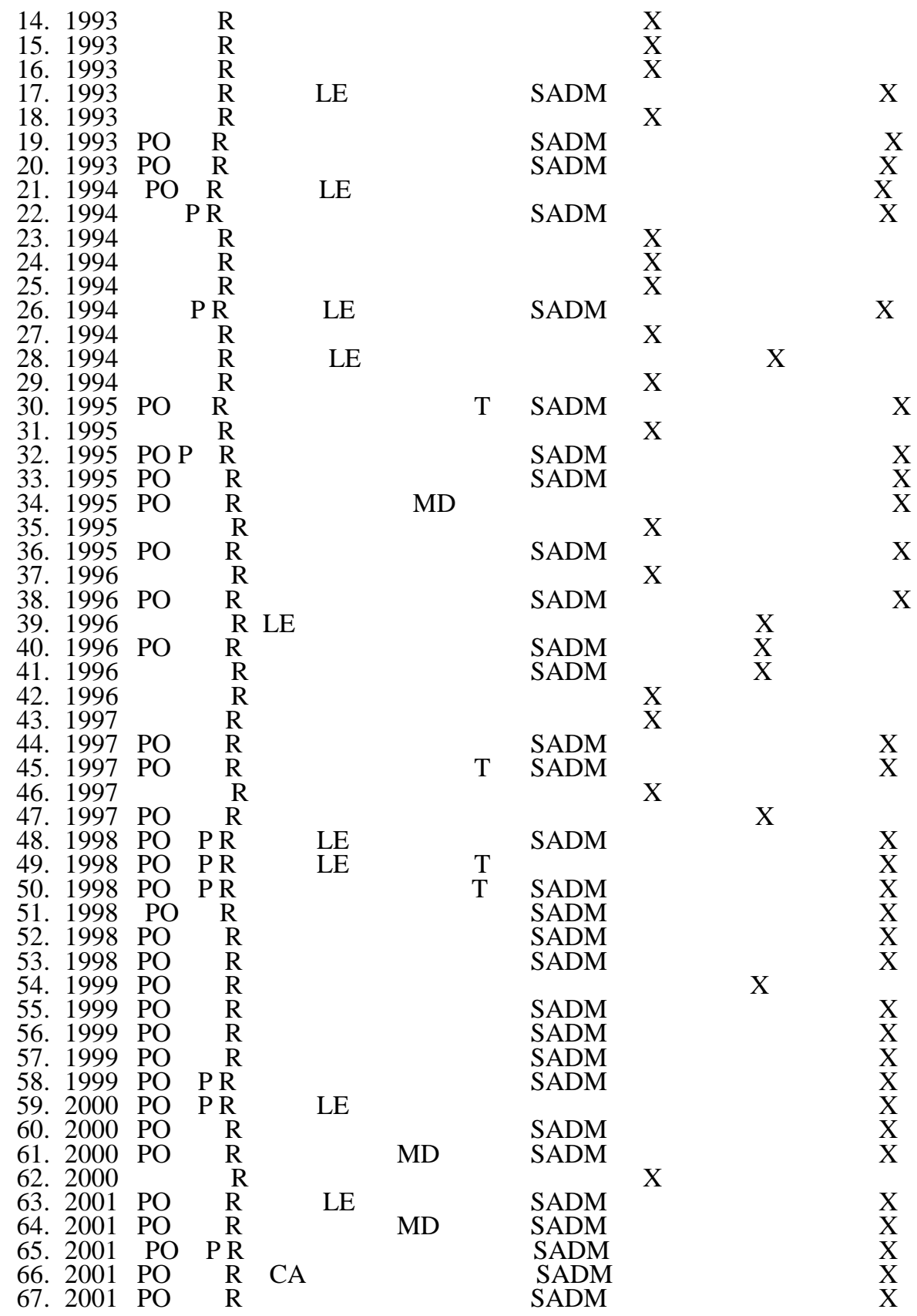

Police Officer(PO), Politician (P), Reporter (R), Community Activist (CA), Legal Expert (LE), Newsmaking Criminologists (NC), Medical Doctor (MD), School Administration (SADM), and Teacher (T)

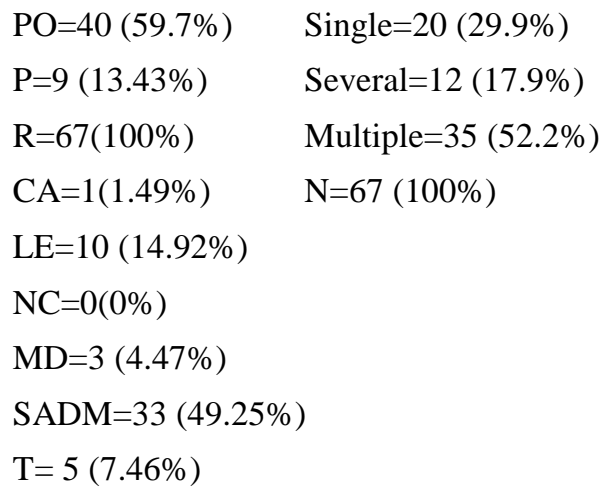


Table 1 shows a systematic sample of 67 items published from 1992 to 2001. It reveals that when it came to who was the spokesperson, or who had ownership of the issue of school violence and shootings, local news reporters (R) were the dominant voices at $100 \%$, followed by police officers (PO) at 59.7\%, school administrators (SADM) at 49.2\%, legal experts (LE) at $14.9 \%$, medical experts (ME) at $4.47 \%$, teachers (T) at $7.4 \%$, and community activists (CA) at $3 \%$, respectively. However, no data revealed the use of any newsmaking criminologists (NC) or the practice of newsmaking criminology. Moreover, the analysis revealed that in the 67 items that were examined, $29.9 \%$ of the reports used a single source, $17.9 \%$ relied on several sources, and $52.2 \%$ used multiple sources.

Overall, the data for this period reflects a movement from relying on only 1-2 sources of information for reporting purposes to seeking out multiple sources of information. More specifically, it reveals that for the 20 shooting events reported from 1992 through 1993, there were 8 single spokespersons, 7 used several spokespersons, and 5 used multiple spokespersons during that time. It shows that for the 16 shooting events reported on during 1994 through 1995, there were 7 single spokespersons used, 1 used several spokespersons, and 8 used multiple spokespersons. Moreover, it reveals that for the 17 shooting events reported from 1996 through 1998, there were 5 single spokespersons used, 2 used several spokespersons, and 10 used multiple spokespersons. In the 14 shootings published from 1999 through 2001, there was 1 single spokesperson used, 1 used several spokespersons, and 12 used multiple spokespersons. In the end, it shows that 47.8 , or 32 of the 67 items, did not use multiple spokespersons. However, 52\%, or 35 items did employ multiple spokespersons.

Table 2. Systematic Sample of 62 Items from 2012 To 2013

Table 2 (2002-2013)

| YearSource

Singular Several Multiple Total Number

PO, P, R, CA, LE, NC, MD, T, SADM

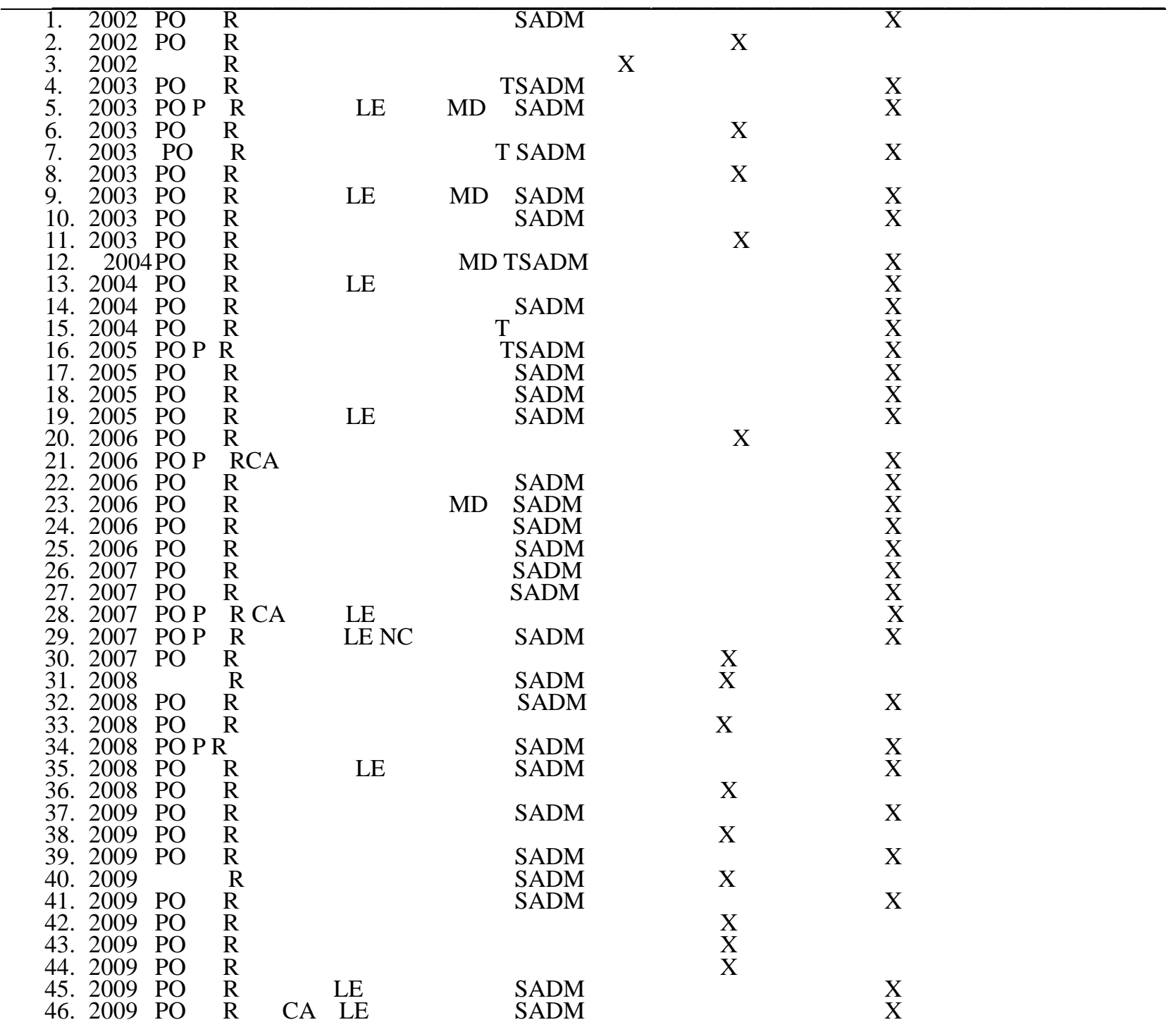




$\begin{array}{llll}\text { 47. } 2009 & \mathrm{PO} & \mathrm{R} \\ \text { 48. } 2009 & \mathrm{PO} & \mathrm{R} \\ \text { 49. } 2010 & \mathrm{PO} & \mathrm{R} \\ \text { 50. } 2010 & \mathrm{PO} \mathrm{P} & \mathrm{R} \\ \text { 51. } 2010 & \mathrm{PO} & \mathrm{R} \\ \text { 52. } 2010 & \mathrm{PO} & \mathrm{R} \\ \text { 53. } 2010 & \mathrm{PO} & \mathrm{R} \\ \text { 54. } 2010 & \mathrm{PO} & \mathrm{R} \\ \text { 55. } 2010 & \mathrm{PO} & \mathrm{R} \\ \text { 56. } & 2010 & \mathrm{PO} & \mathrm{R} \\ \text { 57. } 2011 & \mathrm{PO} & \mathrm{R} \\ \text { 58. } 2012 & \mathrm{PO} & \mathrm{R} \\ \text { 59. } 2012 & \mathrm{PO} \mathrm{P} & \mathrm{R} \\ \text { 60. } 2012 & \mathrm{PO} & \mathrm{R} \\ \text { 61. } 2012 & \mathrm{PO} & \mathrm{R} \\ \text { 62. } 2013 & \mathrm{PO} \mathrm{P} & \mathrm{R}\end{array}$

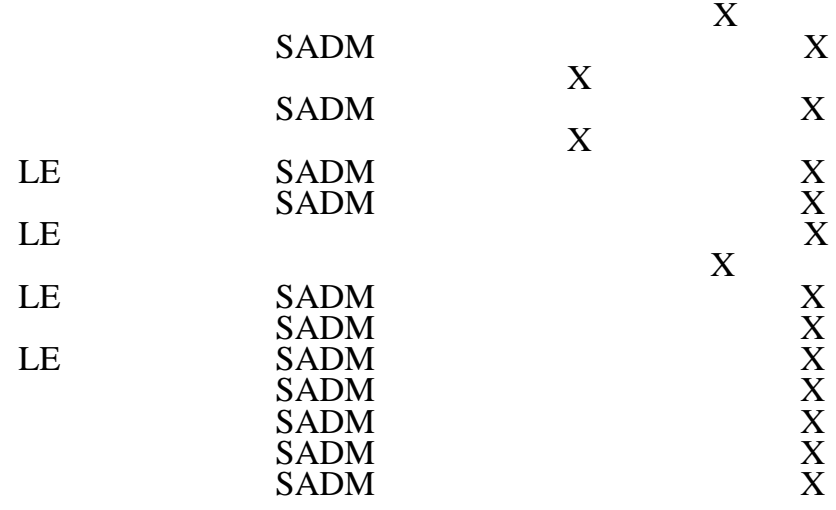

Police Officer(PO), Politician (P), Reporter (R), Community Activist (CA), Legal Expert (LE), Newsmaking Criminologists (NC), Medical Doctor (MD), School Administration (SADM), and Teacher (T)

$\mathrm{N}=62$

$\begin{array}{ll}\mathrm{PO}=59(95.16 \%) & \text { Single=1 }(1.61 \%) \\ \mathrm{P}=9(14.51 \%) & \text { Several= } 19(30.64 \%) \\ \mathrm{R}=62(100 \%) & \text { Multiple=42 }(67.74 \%) \\ \mathrm{CA}=3(4.83 \%) & \mathrm{N}=62(100 \%) \\ \mathrm{LE}=13(20.96 \%) & \\ \mathrm{NC}=1(1.61 \%) & \\ \mathrm{MD}=4(6.45 \%) & \end{array}$

$\mathrm{SADM}=39(62.90 \%)$

$\mathrm{T}=5(8.06 \%)$

Table 2 shows a systematic sample of 62 school shootings reported in the media from 2002 to 2013. It reveals that when it came to who was the spokesperson or who had ownership of the issue of school violence and shootings, local news reporters (R) were the dominant voices at $100 \%$, followed by police officers (PO) at $95 \%$, school administrators (SADM) at $62.9 \%$, legal experts (LE) at 30\%, medical experts (ME) were used at $6.45 \%$, community activists (CA) were used in $4.47 \%$, and Teachers $(\mathrm{T})$ were used in $8.06 \%$. During this 11 year period, while there was no mention of the use of any newsmaking criminologists or the practice of newsmaking criminology, we discovered one report of a social worker at $1.49 \%$. Moreover, the analysis revealed that in the 63 items that were examined, $1.61 \%$ of the reports used a single source, $30.6 \%$ relied on several sources, and $67.7 \%$ used multiple sources.

Overall, Table 2 reveals the continuation of a trend toward using multiple sources of information for reporting purposes. More specifically, it reveals that for school shootings reported from 2002 through 2004, consisting of 15 shootings, there was 1 single spokesperson, 4 used several spokespersons, and 10 used multiple spokespersons during that time. It shows that for shootings reported during 2005 through 2007, consisting of 15 occurrences, there were 0 single spokespersons used, 2 used several spokespersons, and 13 used multiple spokespersons. Moreover, it reveals that in shootings reported from 2008 through 2009, comprised of 18 incidents, there were 0 single spokespersons used, 9 used severalspokes persons, and 9 used multiple spokespersons. In shootings reported on from 2010 through 2013, containing 14 shootings, there were 0 single spokespersons used, 3 used several spokespersons, and 11 used multiple spokespersons. In the end, it shows that $31 \%$, or 19 of the 62 items did not use multiple spokespersons. However, $69 \%$ used multiple spokespersons.

\section{Enlisting the Help of Newsmaking Criminologists and Expanding Its Practice to Social Workers}

Between December 2012 and June 2014, there were 74 school shootings, or nearly one shooting per week (Fantz, Knight, \& Wang, 2014). To many people, this may signal failed efforts to understand school shootings and the persons instigating violence perpetrated against themselves and others. The numbers may also speak to the issue of failed prevention efforts. Nevertheless, when the media reports on these incidents, they have almost exclusively turned to predictable news sources for information: police authorities, legal experts, school administrators, and teachers, as well as students and family members involved. Those who are hardly sought after for their expert analysis, opinions, and commentary are physicians, psychologists, and psychiatrists. To the point, in our investigation, we discovered that in 
only one instance, a social worker was interviewed in response to the aftermath of school violence. This suggests that the media relies on sources that are convenient, and not necessarily the most knowledgeable or notable about the causes, ramifications, and consequences of violence in general, and school shootings, in particular. We also found that typically news reports on school shootings are disproportionately based on eye witness accounts. At times, there were significant discrepancies about the facts as reported in the various media outlets. In fact, for some deaths, there was nothing to be found other than a brief statement written by a single reporter.

Newsmaking criminology as explained earlier in this work is the practice of actively engaging the media to present the reality of crime and justice. More specifically, those experts using this practice should be professionally trained and educated about crime in general, specific behaviors that are injurious to society, and about justice in particular. Most importantly, these experts use the media to inform the public in a non-sensation seeking and non-biased manner to effectively present the reality of certain behaviors and the possible resultant events (Henry, 1994; Greek, 1994). This could add distinct and significant dimensions of truth and understanding that are consistently absent from the media accounts of the school shootings that have transpired over the past twenty-one years. Moreover, an educated public is different from one that is simply given news information since education allows for the objective processing of information in such a way that it is of value for meaning-making, whereas news in-and-of itself may only evoke innate reactions to a tragedy. Along with confusion and emotions attached to school shootings, inaccurate data, poor journalism, and assumptions about the event seemingly go unchallenged. Consequently, those who engage in newsmaking criminology are trained to ensure that crime reports provide an accurate reality and are not distorted, and that the information disseminated to the public is useable. Traditionally, newsmaking criminologists have been understood to only include criminologists and some criminal justicians. However, we argue that the practice should be expanded to include social workers since they bring a highly valued level of expertise and understanding of everyone involved in school shooting tragedies ranging from perpetrators, victims, and the degree of suffering and treatment needed by those in a community that have experienced violence directly as well as indirectly. Arguably, social workers may know more about locating appropriate treatment centers and healing agencies than their criminal justice and criminological counterparts. The treatment and healing aspect or consequence of crime and violence may be addressed differently by social workers. Therefore, their expertise and voice should be part of the discussion.

The link between criminal activity, such as school shootings, and criminologists and criminal justicians may appear more relevant than between criminal activity and social workers. Social workers have not previously been considered as those who participate in newsmaking criminology, but the relationship is plausible. For example, it is widely known that social workers engage in therapeutic interactions with both youth and adult perpetrators of crime, in the roles of case manager, advocate, counselor, therapist, and probation officer. They may influence policy or serve as a prevention specialist. Their roles also touch the lives of victims of violence. However, being recognized as an expert reporter on crime and justice is a very different societal function.

Monell $(2014$, p5) provides that "social workers are trained to pay attention, to notice, and to probe the behaviors of the people we interact with on a daily basis." Monell, a forensic social worker, has discussed social workers focusing on how events unfold more so than on the reasons why they might occur. For example, a social worker is more likely to concentrate on the early behavioral cues of violence perpetrators and how those cues went ignored or unnoticed, as compared to others who may theorize about motives for violence. Social workers might not perceive school violence as a school structural problem, or as a failure on the school's part to react appropriately to interpersonal violence occurring at school. Instead, social workers may be more inclined to examine the home or community for clues regarding why violence is carried out in the school environment (Cawood, 2013). This is known as utilizing the biopsychosocial perspective for understanding how behaviors develop, and for creating more effective violence prevention measures.

Similar to criminologists and criminal justicians, social workers draw from a myriad of theories, some of which are even used in both social work and criminology, such as the strain theory (Weller, Bowen, \& Bowen, 2013). This theory posits that the type of noncompliant behavior which emerges is in direct relationship to the type of environmental strain being experienced. If the behavioral cues are noticed, social workers can then assess a person's environment to construct appropriate behavioral interventions that are aimed at correcting ill- adaptive mechanisms used to cope with strain. For example, some youth and adults might be reacting to one of the three types of popular strain: anticipated strain that occurs when a person fears being victimized; vicarious strain which is due to being a witness to violence; and experienced strain is when someone has actually experienced violence, such as bullying. In terms of school violence, social workers are probably the most adept at both educating the public about these matters and effectively assessing and intervening on nonconforming or disobedient behavior before a tragedy occurs. 


\subsection{Accomplishing Newsmaking Criminology}

In order to effectively accomplish the practice of newsmaking criminology, the criminal justician, criminologist, social worker, or any other professional must first present the objective reality on all matters related to crime and justice and become an expert on the media. Perhaps of the two requirements, the latter is more challenging since one does not instantaneously become an expert on the media. In point of fact, how does one become an expert on the media? Must the expert (academic or practitioner) become a journalist or at the minimum learn to think as a journalist or news reporter? Should he or she have journalists, reporters, and editors as contacts? Should these experts learn to write and deliver news releases? For many, this may be a radical departure from writing and researching styles that they have grown accustom to, especially if their writings are typically peer reviewed or read by other practitioners. After all, they would be writing and reporting to a different audience with diverse backgrounds including different levels of education. Nevertheless, those engaging in the practice of newsmaking must learn to use the media to inform the public on the reality of crime and justice even if it means demystifying or unmasking the truth about areas the public has simply taken for granted as being reported as true. The processing of doing newsmaking will also require learning who is in charge of different news departments. It will invariably mean identifying the editor in charge so that they can either consult or send their independent work to the appropriate person in order to save time and to get their news releases out (Fedler et al., 1997). Moreover, when it comes to being interviewed on public radio or participating in radio broadcasting, newsmaking criminology requires flexibility.

\section{Conclusion}

At the beginning of our investigation, we presented two hypotheses: First, newsmaking criminology is not being used to inform the general public about school violence and shootings. Second, reports of school violence and shootings do not use multiple sources that may increase the likelihood of reaching a wider audience and offering more perspective as to why these events transpire and what can be done to prevent them. Because of the serious nature of school shootings, we believe that multiple sources are necessary since they can better inform the public about the nature and extent of such behavior and invariably help lead to prevention. The results from our research were mixed. We did find support for the first hypothesis, in that, we discovered only one case where a social worker spoke on the issue of school violence and shootings, but never a criminologist or criminal justician.

We also found that of the 129 items that were systematically selected for this twenty-one year period, when we divided these data into two periods from (1992-2001) and (2002-2013), multiple sources were used at 52\% and 69\%, respectively. While the use of multiple sources has increase over the years, more experts need to be spokespersons because of the serious nature of school shootings. More specifically, the study reveals that the majority of sources used by the media that were published during this period, disproportionately relied on law enforcement, news reporters, and school officials, respectively. Our explanation for this is twofold: First, police, reporters, and school officials are easily among the first to respond on the crime scene to school shootings. More specifically, police investigate the facts in these matters to make arrests, reporters inform the viewing public about these matters, and school officials update parents and television viewers on the circumstances and impact that shootings have on their respective campuses. Furthermore, these sources provide a different level of involvement and participation. This is not the case for the practice of newsmaking criminology or this group of experts who the public may know very little about.

Our sample and research findings did not reveal evidence of newsmaking criminology efforts in the literature from 1992 through 2013. This does not mean that experts using this practice are not working behind the scenes with the media, meeting and working with editors and reporters, helping media with the reality of facts, attending town hall meetings, utilizing social media, or engaging in other activities. What it means is that the content analysis method is unable to detect activities that are not published in the literature. Therefore, further research should be conducted to uncover the impact of newsmaking criminology on activities that are not reported in the literature. With that said, we challenge those who engage in newsmaking criminology (e.g., criminologists, criminal justicians, social workers and others) to incorporate their important work into the academic literature. We believe that the practice of newsmaking criminology can better explain and impact public policies that will effect change.

\section{References}

Anderson, J. F., Mangels, N. J., \& Dyson, L. (2003). Criminal Justice and Criminology: A Career Guide to Local, State, Federal, and Academic Positions. Landam, MD: University Press of America.

Bachman, R., \& Schutt, R. K. (2008). Fundamentals of Research in Criminology and Criminal Justice. Thousand Oaks, CA: Sage.

Barak, G. (1988). Newsmaking Criminology: Reflections on the Media, Intellectuals, and Crime. Justice Quarterly (JQ), 5(4), 565-587. 
Barak, G. (1998). Integrating Criminologies. Needham Heights, MA: Allyn and Bacon.

Barak, G. (2007). Doing Newsmaking Criminology from Within the Academy. Theoretical Criminology (TC), 11(2), 191-207.

Barak, G., \& Bohm, B. (1989). The Crimes of the Homeless or the Crime of Homelessness. Contemporary Crises: Law, Crime, and Social Policy (CCLCSP), 13(4), 275-288.

Barkan, S. E. (2006). Criminology: A Sociological Understanding ( $3^{\text {rd }}$ ed.). Upper Saddle, NJ: Pearson/ Prentice-Hall.

Bryman, A. (2012). Social Research Methods (4 ${ }^{\text {th }}$ ed.). New York, NY: Oxford University Press.

Bureau of Justice Statistics, National Institute of Justice, Surveys of DNA Crime Laboratories, 1998. (Washington, D.C.: Department of Justice, Feb, 2000), 1 .

Bureau of Labor Statistics, (2014a). Occupational outlook handbook, 2014-15 edition: Social workers. Retrieved from http://www.bls.gov/ooh/community-and-social-service/social-workers.htm

Bureau of Labor Statistics, (2014b). Occupational outlook handbook, 2014-15 editions: Probation officers and correctional treatment specialists. Retrieved from

http://www.bls.gov/ooh/community-and-social-service/probation-officers-and-correctional-treatment-specialists.ht $\mathrm{m}$

Cawood, N. D. (2013). Violent Events: School Social Workers' Perception and Response. School Social Work Journal (SSWJ), 37(2), 21-36.

Champion, D. J. (1993). Research Methods for Criminal Justice and Criminology. Englewood Cliffs, NJ: Regents/Prentice-Hall.

DuBois, B., \& Miley, K. (2014). Social Work: An Empowering Profession. ( $8^{\text {th }}$ ed.). New York: Pearson.

Fantz, A., Knight, L., \& Wang, K. (2014). A closer look: How many Newtown-like school shootings since Sandy Hook? Retrieved from http://www.cnn.com/2014/06/11/us/school-shootings-cnn-number/index.html

Fedler, F., Bender, J. R., Davenport, L., \& Kostyu, P. E. (1997). Reporting for the Media (6 ${ }^{\text {th }}$ ed.). Fort Worth, TX: Harcourt Brace College Publishers.

Ferrell, J., \& Sanders, C. R. (1995). Cultural Criminology. Boston: Northeastern University Press.

Fox, J. A., \& Levin, J. (1993). How to Work with the Media. Newbury Park, CA: Sage

Greek, C. E. (1994). Becoming a Media Criminologists: Is Newsmaking Criminology Possible? , Media, Process, and the Social Construction of Crime, 265-286, by Gregg Barak (Ed). New York: Garland Publishing, 1994.

Hagan, F. E. (2014). Research Methods in Criminall Justice and Criminology (9 $9^{\text {th }}$ ed.). Upper Saddle River, NJ: Pearson.

Haight, W. \& Taylor, E. (2013). Human Behavior for Social Work Practice: A Developmental-Ecological Framework. Chicago, IL: Lyceum Books.

Hawkins, N. A., McIntosh, D. N., Cohen-Silver, R., \& Holman, E. A. (2004). Early Responses to School Violence: A Qualitative Analysis of Students' and Parents' Immediate Reactions to the Shootings at Columbine High School. Journal of Emotional Abuse (JEA), 4, 197-223.

Henry, S. (1994). Newsmaking Criminology as Replacement Discourse, Media, Process, and the Social Construction of Crime, 287-318, by Gregg Barak (Ed). New York: Garland Publishing, 1994.

Jewkes, Y. (2004). Media \& Crime. London, U.K.: Sage Publications.

Kappaler, V. E., \& Potter, G. W. (2005). The Mythology of Crime and Criminal Justice (4 ${ }^{\text {th }}$ ed.). Prospect Heights, IL: Waveland Press.

Kraska, P. B., \& Neuman, W. L. (2012). Criminal Justice and Criminology Research Methods (2 ${ }^{\text {nd }}$ ed.). Upper Saddle River, NJ: Pearson.

Lanier, M. K., \& Briggs, L. T. (2014). Research Methods in Criminal Justice and Criminology: A Mixed Methods Approach. New York, NY: Oxford University Press.

Levy, S., \& Stone, B. (2000). Hunting the Hackers. Newsweek, 38-44.

Libermann, J. (2001). Name Your Own Price for Hookers, E-bay and Priceline.com Muscle In on the World's Oldest Business Model at http://www.petyrant.com/hookers.html.

Lovrich, N., Pratt, T., Travis, C., Gaffney, M., Johnson, C., Asplen, C., Hurst, L., \& Schellberg, T. (2004). National 
Forensic DNA Study Report. Washington, DC: US Department of Justice.

Maguire, B., Sandage, D., \& Weatherby, G. A. (1999). Crime Stories as Television News: A Content Analysis of National, Big City, and Small Town Newscast. Journal of Criminal Justice and Popular Culture (JCJPC), 7(1), $1-44$.

Maxfield, M. G., \& Babbie, E. R. (2011). Research Methods for Criminal Justice and Criminology (6 ${ }^{\text {th }}$ ed.). Belmont, CA: Wadsworth Cengage Learning.

Mills, C. W. (1951). White Collar. New York, NY: Oxford University Press.

Monell, J. (2014, November 06). Another school shooting: Millennial anger? Social Work Helper. Retrieved from http://www.socialworkhelper.com/2014/06/11/another-school-shooting-millennial-anger/

Moore, R. (2005). Cybercrime: Investigating High Technology Computer Crime. Cincinnati, OH: Anderson.

National Organization of Forensic Social Work. (2014). Forensic social work: What is forensic social work. Retrieved from http://nofsw.org/?page_id=10

Ripski, M. B., \& Gregory, A. (2009). Unfair, Unsafe, and Unwelcome: Do High School Students' Perception of Unfairness, Hostility and Victimization in School Predict Engagement and Achievement? Journal of School Violence (JSV), 8(4), 355-375.

Salva, L., \& Bohm, B. (1987). Law and Liberation: Toward an Oppositional Legal Discourse. Legal Studies Forum (LSF), 113, 255-76.

Schram, P. J., \& Tibbetts, S. G. (2014). Introduction to Criminology. Thousand Oaks, CA: Sage.

Schreck, C. J., \& Miller, J. M. (2003). Sources of Fear of Crime at School: What is the Relative Contribution of Disorder, Individual Characteristics, and School Security? Journal of School Violence (JSV), 2(4), 57-79.

Siegel, L. J. (2009). Criminology (10 ${ }^{\text {th }}$ ed.). Belmont, CA: Thomson/Wadsworth.

Surette, R. (1992). Media, Crime, and Criminal Justice: Images and Realities. Pacific Grove, CA: Brooks/Cole.

Surette, R. (1998). Media, Crime, and Criminal Justice: Images and Realities ( ${ }^{\text {nd }}$ ed). Belmont, CA: Wadsworth Publishing.

Swanson, C. S., Chamelin, N.C., Territo, L, \& Taylor, R. W. (2009). Criminal Investigation (10 ${ }^{\text {th }}$ ed.). New York, NY: McGraw Hill.

Weller, B., Bowen, N., \& Bowen, G. (2013). Linking Students to Appropriate Interventions: A Typology for Social Workers Based on General Strain Theory. Journal of Social Work (JSW), 13(4), 361-381.

Wike, T. L., \& Fraser, M. W. (2009). School Shootings: Making Sense of the Senseless. Aggression and Violent Behavior (AVB), 14(3), 162-169.

Wood, S. N. (2005). Mapping School Geographies: Teaching and Learning in Unsafe Places. Journal of School Violence (JSV), 4(1), 71-89.

Wright, R., \& Miller, J. M. (2005). Criminology as Social Science. Encyclopedia of Criminology, New York, NY: Routledge Publisher.

Zastrow, C., \& Kirst-Ashman, K. (2013). Understanding Human Behavior and the Social Environment. Belmont, CA: Brooks/Cole.

\section{$(\mathrm{cc}) \mathrm{BY}$}

This work is licensed under a Creative Commons Attribution 3.0 License. 